\title{
Friedmanniella spumicola sp. nov. and Friedmanniella capsulata sp. nov. from activated sludge foam: Gram-positive cocci that grow in aggregates of repeating groups of cocci
}

\author{
A. M. Maszenan, ${ }^{1}$ R. J. Seviour, ${ }^{1}$ B. K. C. Patel, ${ }^{2}$ P. Schumann, ${ }^{3}$ \\ J. Burghardt, ${ }^{3}$ R. I. Webb, ${ }^{4}$ J. A. Soddell ${ }^{1}$ and G. N. Rees ${ }^{5}$
}

Author for correspondence: R. J. Seviour. Tel: +61 0354 447459. Fax: +61 0354447476 e-mail: r.seviour@latrobe.edu.au

\footnotetext{
Biotechnology Research Centre, La Trobe University, Bendigo, Victoria 3550, Australia

2 Faculty of Science and Technology, Griffith University, Nathan, Brisbane, Queensland 4111, Australia

${ }^{3}$ DSMZ - Deutsche Sammlung von Mikroorganismen und Zellkulturen $\mathrm{GmbH}$, D-38124 Braunschweig. Germany

${ }^{4}$ Centre for Microscopy and Microanalysis, Dept of Microbiology, The University of Queensland, St Lucia, Brisbane, Queensland 4072, Australia

${ }^{5}$ CRC Freshwater Ecology Research Centre, Albury, New South Wales 2640, Australia
}

\begin{abstract}
Two Gram-positive, non-motile, non-spore-forming, strictly aerobic, pigmented cocci, strains Ben $107^{\top}$ and Ben $108^{\top}$, growing in aggregates were isolated from activated sludge samples by micromanipulation. Both possessed the rare type A3 $\gamma^{\prime}$ peptidoglycan. Major menaquinones of strain Ben $107^{\top}$ were $M K-9\left(H_{4}\right)$ and MK-7 $\left(\mathrm{H}_{2}\right)$, and the main cellular fatty acid was 12 -methyltetradecanoic acid (ai- $\left.\mathrm{C}_{15: 0}\right)$. In strain Ben 108', MK-9 $\left(\mathrm{H}_{4}\right)$, MK-9 $\left(\mathrm{H}_{2}\right)$ and MK-7 $\left(\mathrm{H}_{4}\right)$ were the menaquinones and again the main fatty acid was 12 -methyltetradecanoic acid (ai- $C_{15: 0}$ ). Polar lipids in both strains consisted of phosphatidyl inositol, phosphatidyl glycerol and diphosphatidyl glycerol with two other unidentified glycolipids and phospholipids also present in both. These data, together with the 165 rDNA sequence data, suggest that strain Ben $107^{\top}$ belongs to the genus Friedmanniella which presently includes a single recently described species, Friedmanniella antarctica. Although the taxonomic status of strain Ben ${ }^{108}{ }^{\top}$ is far less certain, on the basis of its 165 rRNA sequence it is also adjudged to be best placed in the genus Friedmanniella. The chemotaxonomic characteristics and DNA-DNA hybridization data support the view that Ben $107^{\top}$ and Ben $108^{\top}$ are novel species of the genus Friedmanniella. Hence, it is proposed that strain Ben $107^{\top}$ ( = ACM 5121') is named as Friedmanniella spumicola sp. nov. and strain Ben $108^{\top}$ ( = ACM 5120') as Friedmanniella capsulata sp. nov.
\end{abstract}

Keywords: activated sludge, G-bacteria, Gram-positive cocci, Friedmanniella, Microlunatus

\section{INTRODUCTION}

Cocci are widely seen in many activated sludge biomass samples, especially those from aerobic/anaerobic enhanced biological nutrient removal plants (Knight et al., 1995) and sequencing batch reactors (SBR) (Bond et al., 1997; Liu et al., 1996; Randall et al., 1994;

Abbreviations: $A_{2} p m$, diaminopimelic acid; EBPR, enhanced biological phosphorus removal; PolyP, polyphosphate; SBR, sequencing batch reactors; $S_{S M}$ simple matching coefficients; UPGMA, unweighted pair group with mathematical averages.

The GenBank accession numbers for the 16S rRNA sequences of strains Ben $107^{\top}$ (=ACM 5121 ${ }^{\top}$ ) and Ben $108^{\top}$ (=ACM 5120 ) are AF062535 and AF084529, respectively.
Carucci et al., 1994; Cech \& Hartman, 1993). The Gram-negative cocci, the so-called ' $\mathrm{G}$ ' bacteria (Cech \& Hartman, 1993) have been isolated and their taxonomy resolved (Maszenan et al., 1997). Four isolates from different parts of the world were all shown to be separate species belonging to a single new genus Amaricoccus (Maszenan et al., 1997). Amaricoccus kaplicensis has also been named, albeit invalidly, as 'Tetracoccus cechii' by Blackall et al. (1997).

However, Gram-positive cocci are also present in activated sludge and some of these have been cultured and their taxonomy resolved (Maszenan et al., 1999), while others still remain unidentified or uncultured 
(Katoaka et al., 1996; Matsuo, 1994; Matsuzawa \& Mino, 1991). The Gram-positive cocci which have been cultured from activated sludge include Microlunatus phosphovorus (Nakamura et al., 1995) in the family Propionibacteriaceae, suborder Propionibacterineae (Stackebrandt et al., 1997), and Microsphaera multipartita (Yoshimi et al., 1996) in the family Microsphaeraceae, suborder Frankineae (Stackebrandt et al., 1997). Both isolates were obtained in Japan and are slow-growing organisms with $\mathrm{G}+\mathrm{C}$ values of about $70 \mathrm{~mol} \%$. Neither have been reported elsewhere in the world. Chemotaxonomically, $M$. phosphovorus has type A $3 \gamma^{\prime}$ peptidoglycan (Schumann et al., 1997), whereas $M$. multipartita has meso-diaminopimelic acid (meso- $\mathrm{A}_{2} \mathrm{pm}$ ) in its cell wall (Yoshimi et al., 1996). Recently, we isolated another Gram-positive coccus, Tessaracoccus bendigoensis, from a laboratory-scale SBR (Maszenan et al., 1999). Based on its 16S rDNA sequence, it was also shown to be a member of the high-G + C-containing Gram-positive bacteria, suborder Propionibacterineae (Stackebrandt et al., 1997). The description of this novel isolate, together with data from descriptions of $M$. phosphovorus (Nakamura et al., 1995) and M. multipartita (Yoshimi et al., 1996), illustrates the taxonomic diversity among the high$\mathrm{G}+\mathrm{C}$ Gram-positive cocci found in activated sludge systems.

Other studies (Katoaka et al., 1996; Bond et al., 1995; Ubukata et al., 1994; Wagner et al., 1994; Liu et al., 1996) would suggest that other Gram-positive cocci are also present in activated sludge systems, although none of the organisms seen in these studies in microscopic examinations of biomass samples has been obtained in pure culture. It has been suggested that cocci play an undesirable role in enhanced biological phosphorus removal (EBPR) plants, accumulating carbohydrate (as glycogen) and not polyphosphate (Cech \& Hartman, 1993). As part of our ongoing research into studying these cocci in activated sludge biomass, we successfully isolated two orange cocci arranged in aggregates from activated sludge samples in Australia. This paper describes the taxonomy of these isolates after chemotaxonomic characterization and phylogenetic analysis and places them as novel species of the genus Friedmanniella (Schumann et al., 1997).

\section{METHODS}

Isolation and maintenance of bacterial strains. Strain Ben $107^{\mathrm{T}}$ was isolated from a stable foam on the surface of the aerobic reactor in an activated sludge plant treating mainly wastewater from an orange-juice-processing plant in Mildura, Victoria, Australia by micromanipulation; a Skerman micromanipulator (Skerman et al., 1968) was used to separate cells from filamentous organisms present in the sample. Strain Ben $108^{\mathrm{T}}$ was obtained from a sample of activated sludge biomass from Hayman Island, Queensland, Australia. Both were successfully micromanipulated (Maszenan et al., 1997) onto plates of standard methods agar (SMA; Difco) supplemented with 1\% sterile horse serum, which were then incubated at $25^{\circ} \mathrm{C}$. Growth was monitored microscopically to check for contamination and, when colonies had developed (usually after 7-10 d), strains Ben $107^{\mathrm{T}}$ and Ben $108^{\mathrm{T}}$ were streaked onto fresh plates of R2A agar (Reasoner \& Geldreich, 1985). Purity of the micromanipulated cells was checked microscopically and the purified culture was stored at $-80^{\circ} \mathrm{C}$ in $\mathrm{R} 2 \mathrm{~A}$ medium in $20 \%$ glycerol. The type strain of Friedmanniella antarctica (Schumann et al., 1997) was grown on R-medium (Yamada \& Komagata, 1972).

Staining procedures and morphology studies. Gram stains were performed according to the modified Hucker method (Hucker, 1921) and confirmed by using 3\% KOH (Buck, 1982).

Physiological and biochemical characterization. Enzyme profiles and biochemical characteristics of strains Ben $107^{\mathrm{T}}$ and Ben $108^{\mathrm{T}}$ and $F$. antarctica were determined using the API ZYM (bioMérieux) and Microbact 24E (Oxoid) systems according to the manufacturers' instructions. Carbon substrate utilization tests were performed with the BIOLOG GN and GP (Special Diagnostics) systems, or by the methods described by Goodfellow (1971). The results obtained by the two different methods agreed in most cases, although some discrepancies, as indicated in results, were noticed.

Oxidase and catalase activities were determined using standard methods (Smibert \& Krieg, 1994). The presence of possible storage granules was detected by microscopic examination of cells after staining according to the method of Rees et al. (1992). Cells were grown aerobically in R2A medium incorporating either glucose, acetate or propionate for detection of storage compounds at an initial concentration of $0.15 \mathrm{~g} \mathrm{l}^{-1}$. Urease activity, nitrate reduction and motility were determined according to methods previously described (Maszenan et al., 1997).

The physiological and biochemical data for strains Ben $107^{\mathrm{T}}$ and Ben $108^{\mathrm{T}}$ and $F$. antarctica together with $T$. bendigoensis and $M$. phosphovorus were analysed with numerical taxonomy using the simple matching coefficients $\left(S_{\mathrm{SM}}\right)$ and the unweighted pair group with mathematical averages (UPGMA) clustering algorithm (Sneath \& Sokal, 1973), and the NTSYS-PC software package, version 1.80 (Exeter Software).

Chemical inhibitor tolerance and penicillin inhibition tests. R2A medium was the basal medium used for chemical tolerance tests. Crystal violet $(0.001$ and $0.0001 \%)$, phenol $(0.1$ and $0.3 \%)$, phenyl ethanol $(0.03 \%)$, sodium azide $(0 \cdot 1$ and $0 \cdot 2 \%)$ and $\mathrm{NaCl}(5$ and $7 \%)$ were added (final concentrations are shown in parentheses). Cultures were inoculated and any sign of growth was considered positive and taken to mean that the organism was tolerant to that concentration of chemical tested (Goodfellow \& Pirouz, 1982). Penicillin sensitivity tests were conducted by placing penicillin disks (Oxoid) at 10 IU concentration on the lawn of R2A plates, prepared by inoculating with swabs soaked in suspensions of cells of strains Ben $107^{\mathrm{T}}$ or Ben $108^{\mathrm{T}}$. Plates were incubated at $25^{\circ} \mathrm{C}$ for 2 weeks. If no zone appeared around the disc, then the organism was resistant to penicillin at that concentration.

Culture conditions. The biomass used for phylogenetic studies was obtained by growing strains Ben $107^{\mathrm{T}}$ and Ben $108^{\mathrm{T}}$ aerobically in R2A broth or on R2A agar at $25^{\circ} \mathrm{C}$ for 2 weeks. $F$. antarctica was grown on R-medium (Yamada \& 
Komagata, 1972). The biomass for chemotaxonomic analyses was obtained by cultivating strains Ben $107^{\mathrm{T}}$ and Ben $108^{\mathrm{T}}$ on R-agar at $22^{\circ} \mathrm{C}$ for $2-3$ weeks.

Electron microscopy. Cells for TEM studies were prepared by cryofixation and cryosubstitution protocols as described by Lindsay et al. (1997), using osmium tetraoxide in acetone and embedding the material in epon resin. For chemical fixation studies, cells were fixed in $3 \%$ glutaraldehyde in $0 \cdot 1$ M cacodylate buffer, post-fixed in $1 \%$ osmium tetraoxide in the same buffer and embedded in epon, while specimens were prepared for examination by SEM according to the method of Seviour et al. (1984).

165 rDNA sequence and phylogenetic analysis. The $16 \mathrm{~S}$ rDNA from strains Ben $107^{\mathrm{T}}$ and Ben $108^{\mathrm{T}}$ was amplified, sequenced and analysed as previously described (Maszenan et al., 1997).

DNA base composition. The DNA for base composition determination was isolated using the method of Maszenan et al. (1999) and calculated as previously described (Maszenan et al., 1997).

Chemotaxonomic characterization. Peptidoglycan, menaquinone, cellular fatty acid and polar lipid compositions were all analysed as described by Schumann et al. (1997).

DNA-DNA hybridization. DNA-DNA hybridization was carried out according to the method of De Ley et al. (1970) with the modification described by Huss et al. (1983), using a Gilford System model 2600 spectrophotometer equipped with a Gilford model 2527-R thermoprogrammer and plotter. Renaturation rates were computed with the TRANSFER.BAS program (Jahnke, 1992).

\section{RESULTS}

\section{Culture characteristics}

Strain Ben $107^{\mathrm{T}}$ grew as yellow to pale orange colonies on R2A agar, SMA and R-medium agar, whereas strain Ben $108^{\mathrm{T}}$ grew as bright orange colonies on all three media. The pigments of both were not watersoluble and are probably carotenoids. Cells of both strains stained unevenly with the Gram stain; the staining reaction depended on the time used for ethanol decolorization (data not shown). Both grew slowly on R2A medium, requiring up to 2 weeks for colonies to appear on agar and turbidity to occur in liquid medium. These organisms are aerobic as no growth occurred below the surface of the stab cultures.

The growth temperature range for Ben $107^{\mathrm{T}}$ on $\mathrm{R} 2 \mathrm{~A}$ agar was between $15-37^{\circ} \mathrm{C}$ and the optimum temperature was $25^{\circ} \mathrm{C}$. No growth was observed at $5^{\circ} \mathrm{C}$ or below and at $45^{\circ} \mathrm{C}$ or above. The $\mathrm{pH}$ range supporting growth of strain Ben $107^{\mathrm{T}}$ was between $5 \cdot 5-8 \cdot 0$, with optimal $\mathrm{pH}$ of $7 \cdot 0-7 \cdot 5$. Strain Ben $107^{\mathrm{T}}$ did not grow at $\mathrm{pH} 5 \cdot 0$ or below or at $\mathrm{pH} 8 \cdot 5,9 \cdot 0$ or $9 \cdot 3$, whereas weak growth was observed at $\mathrm{pH} 5.5$. In $\mathrm{R} 2 \mathrm{~A}$ broth, cells tended to attach to the side of the flask and sediment to the bottom as clumps. With strain Ben $108^{\mathrm{T}}$, the growth temperature range was from 20 $25^{\circ} \mathrm{C}$, and no growth was observed at $15^{\circ} \mathrm{C}$ or below and at $30^{\circ} \mathrm{C}$ or above. The $\mathrm{pH}$ range supporting
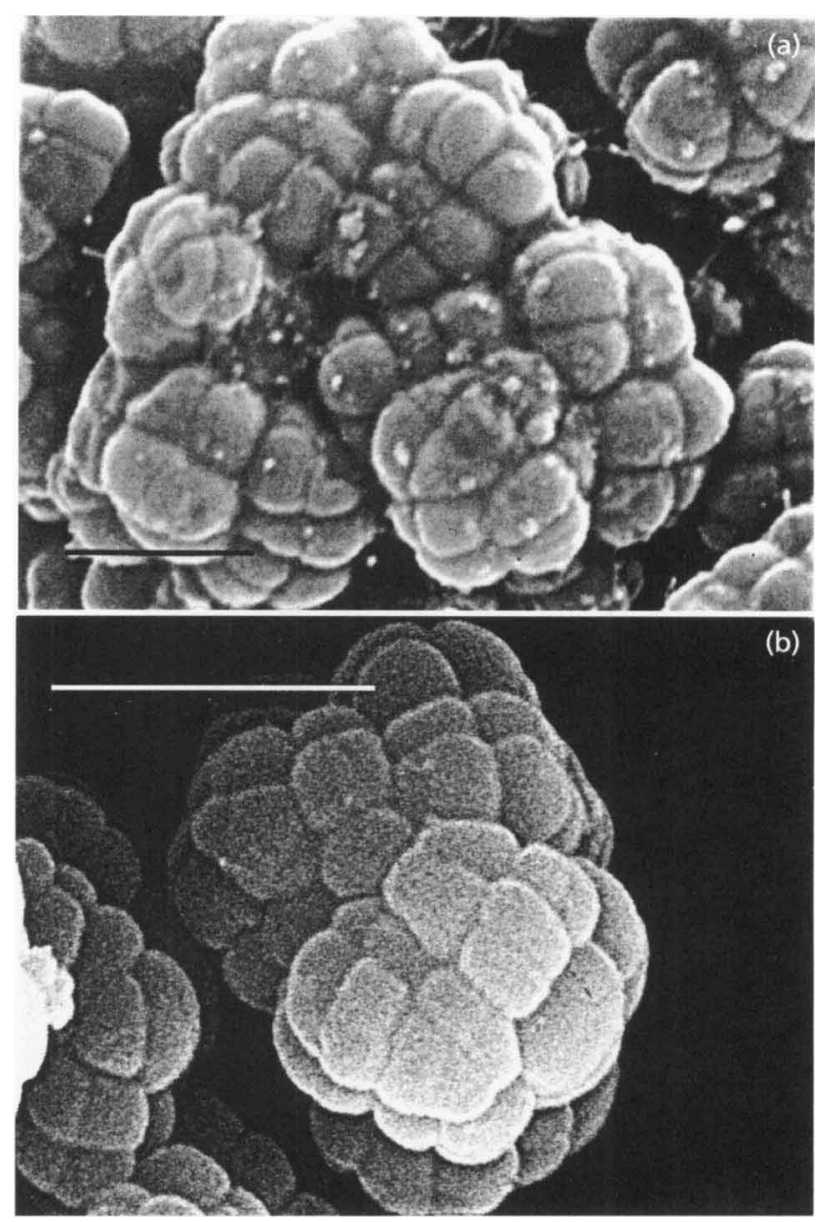

Fig. 1. (a) SEM of strain Ben $107^{\top}$ showing aggregated cells in repeated layers. Bar, $2 \mu \mathrm{m}$. (b) SEM of strain Ben $108^{\top}$ showing coccoid cells in regular packages associated into aggregates. Bar, $2 \mu \mathrm{m}$.

growth of strain Ben $108^{\mathrm{T}}$ was between $5 \cdot 5-7 \cdot 5$, with optimal $\mathrm{pH}$ of $6 \cdot 5-7 \cdot 0$. Strain Ben $108^{\mathrm{T}}$ did not grow at pH $5 \cdot 0$ or below, or at pH $8 \cdot 0,8 \cdot 5,9 \cdot 0$ or $9 \cdot 3$.

\section{Morphological characteristics}

Both organisms grew as clusters of coccoid cells (Fig. 1a, b; Fig. 2a; Fig. 3) where they remained closely associated with each other after cell division as a result of production of extracellular capsular material in large amounts. (Figs 2a). Cells within these clusters were in smaller packages which are delineated by the extracellular material (Figs $2 \mathrm{a}$ and 3). The cell clusters of strain Ben $108^{\mathrm{T}}$ produced a greater amount of a denser extracellular capsule (polysaccharide) than those of strain Ben $107^{\mathrm{T}}$. The cell envelope in both strains was Gram-positive, with an easily discerned cytoplasmic membrane and a wall of $20-26 \mathrm{~nm}$ in thickness (Fig. 2b). The wall was trilaminar, consisting of two electron-dense layers and an inner more electron-translucent layer (Fig. 2b). Cells of both 


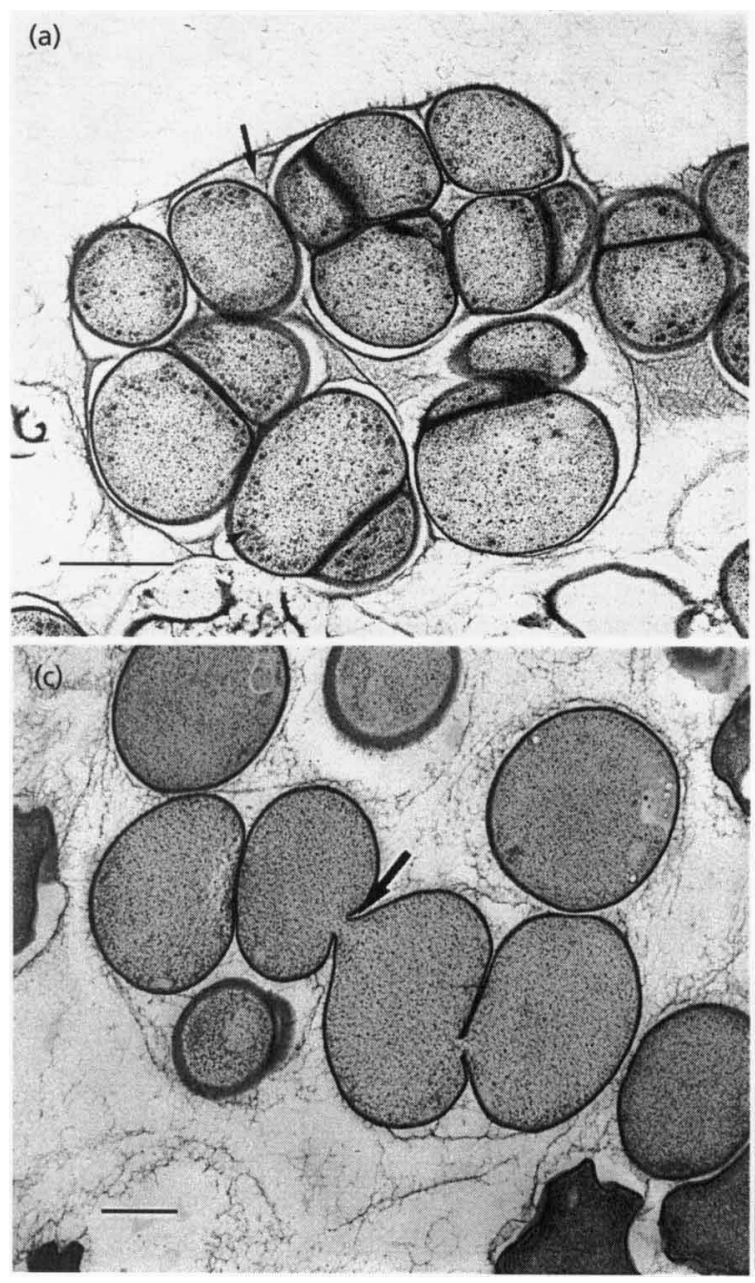

(e)

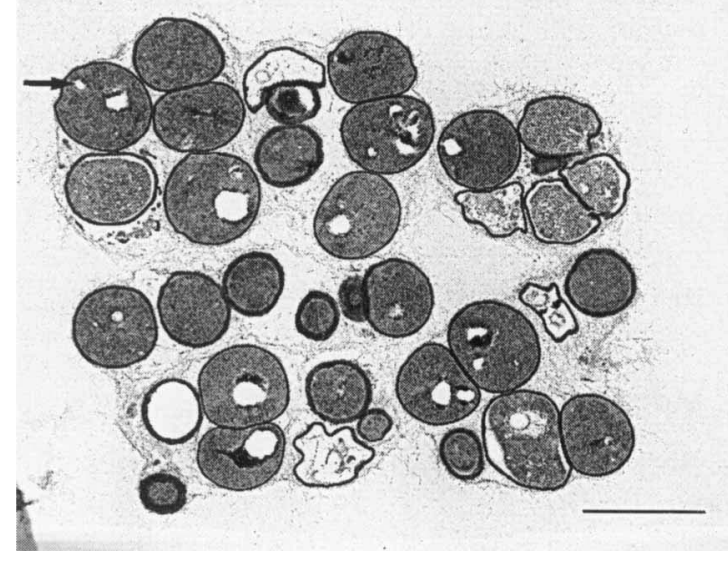

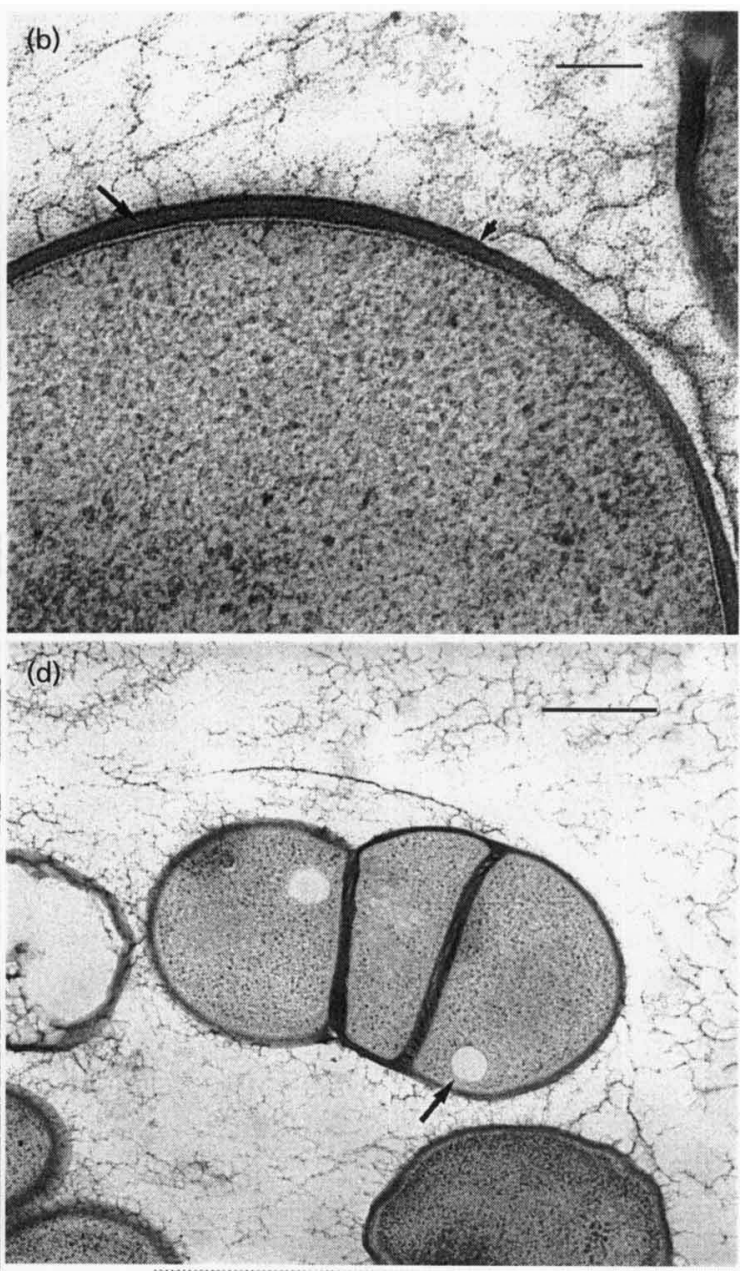

Fig. 2. TEM micrographs of thinly sectioned samples of strain Ben $107^{\top}$ cells. (a) Cluster of cells surrounded by and internally packaged by extracellular capsular material (arrow). Small electron-dense granules (arrowhead) are present in the cells. Bar, 400 $\mathrm{nm}$. (b) Cell envelope showing distinct cell membrane (arrow) and trilaminar cell wall (arrowhead). Bar, $50 \mathrm{~nm}$. (c) Cluster of cells in which some cells display interconnecting bridges (arrow) resulting from incomplete septation. Bar, $400 \mathrm{~nm}$. (d) Cell containing large empty intracellular granules (arrow) which are presumed to be PolyP granules. Bar, $400 \mathrm{~nm}$. (e) Thin section of chemically fixed Ben $107^{\top}$ showing poorly fixed cells displaying holes (arrow) that result from the falling out of intracellular granules during thin sectioning. Bar, $1 \mu \mathrm{m}$. strains divided by septation. Frequently, the septation in strain Ben $107^{\mathrm{T}}$ was incomplete and cells were observed that were well-separated from one another but still connected by a small bridge of cytoplasm (Fig. 2c). Small electron-dense granules were frequently observed in the cytoplasm and were usually more prevalent towards the periphery of the cells (Fig. 2a). The constituents of these granules are unknown. Large intracellular granules were also present in strain Ben
$107^{\mathrm{T}}$ (Fig. 2c), although these appeared to be empty, the contents presumably being lost during processing for electron microscopic observations. These granules may be polyphosphate (PolyP) granules, since this organism stained positively for PolyP when grown aerobically in medium supplemented with glucose, acetate or propionate (data not shown). However, no poly- $\beta$-hydroxyalkanoate granules were observed. No large granules were observed in any cells of strain Ben 


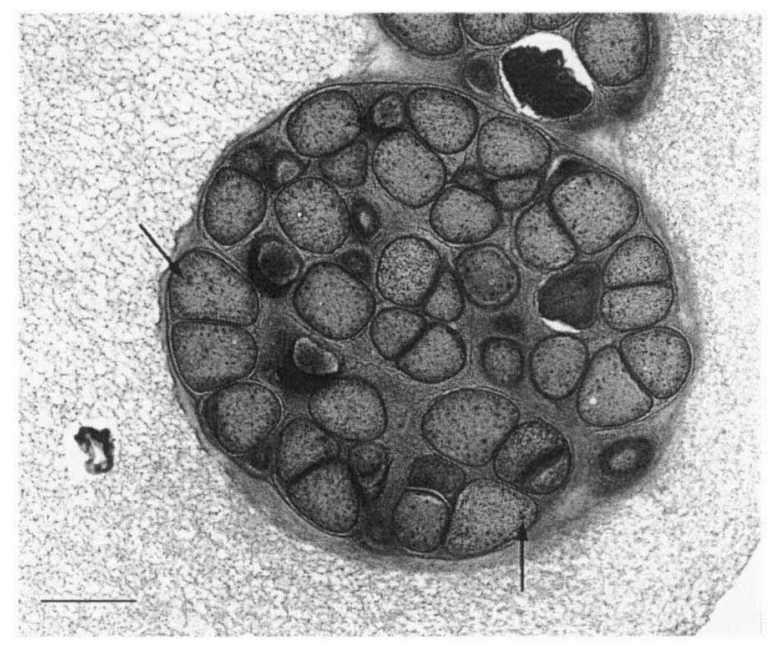

Fig. 3. TEM micrograph of thinly sectioned cryosubstituted samples of strain Ben $108^{\top}$. Cell cluster displaying large amounts of the dense extracellular capsular material which surrounds the cluster and divides it internally into smaller packages of cells. Small electron-dense granules (arrows) are present in the cytoplasm of the cells. Bar, $1 \mu \mathrm{m}$.

$108^{\mathrm{T}}$. These TEM descriptions are based on material preserved by cryofixation and cryosubstitution, a technique which should produce fewer artefacts than standard chemical fixation techniques, thus giving a more correct picture of the ultrastructure (Graham, 1992). Cells of organisms in the present study processed by chemical fixation appeared quite differently (Fig. 2e): the cytoplasm was much more electrondense; cells often had an irregular outline; the extracellular capsular matrix was more diffuse and did not delimit the clusters in the same way; the small electrondense granules and interconnecting bridges of incomplete septation were never seen; and the PolyP granules fell completely out of the section during the thin sectioning process and thus were only observed as holes in cells.

Cells of strain Ben $108^{\mathrm{T}}$ shared some of the features of strain Ben $107^{\mathrm{T}}$. Both strains were also enclosed in extensive capsular material in packets usually of two and four cells (Fig. 3). This capsular material often held them in spherical aggregates. The cell wall organization in strain Ben $108^{\mathrm{T}}$ was not as clearly resolved as in strain Ben $107^{\mathrm{T}}$. However, the wall appeared homogeneous and typically Gram-positive (Fig. 3). Also, no cytoplasmic connections between cells, as seen with strain Ben $107^{\mathrm{T}}$, could be detected here. Furthermore, the cells appeared to lack the granules present in strain Ben $107^{\mathrm{T}}$.

Strains Ben $107^{\mathrm{T}}$ and Ben $108^{\mathrm{T}}$ were both non-motile, lacked flagella and endospores were never observed. Cell stringiness was not seen with $3 \% \mathrm{KOH}$ treatment, which is consistent with strains Ben $107^{\mathrm{T}}$ and Ben $108^{\mathrm{T}}$ both being Gram-positive. The cells were regularly spherical when grown on R2A medium and had diameters of $0.5-1.4$ and $0.6-1.2 \mu \mathrm{m}$ for strains Ben $107^{\mathrm{T}}$ (Fig. 1b) and Ben $108^{\mathrm{T}}$, respectively.

\section{Physiological and biochemical characters}

These results were obtained using the BIOLOG GN and GP systems. In most cases, when these tests were carried out using the methods of Goodfellow (1971), the same results were obtained. However, some discrepancies were observed. Thus, the utilization of glycerol, maltose, melizitose, sucrose and trehalose for strain Ben $107^{\mathrm{T}}$ detected with the methods of Goodfellow (1971) did not show up with the BIOLOG system.

The following substrates were utilized by both strains Ben $107^{\mathrm{T}}$ and Ben $108^{\mathrm{T}}$ : D-ribose, D-arabitol, sebacic acid, L-arabinose, succinate, D-xylose, xylitol, glycogen, methyl $\alpha$-D-glucoside, sorbitol, D-fructose, Dcellobiose, mannitol, dextrin, methyl $\beta$-D-glucoside, amygdalin, arbutin, methyl $\alpha$-D-galactoside, palatinose, D-lactic acid methyl ester, pyruvic acid, adenosine, thymidine-5'-monophosphate and quinic acid. However, the following substrates were utilized only by Ben $107^{\mathrm{T}}$ : i-erythritol, D-saccharic acid, formic acid, D-galactose, turanose, methylpyruvate, $\alpha$-ketobutyric acid, alaninamide and thymidine.

The following compounds were only utilized by strain Ben $108^{\mathrm{T}}$ : L-rhamnose, maltose, sucrose, $\beta$-cyclodextrin, Tween 40, L-fucose, 2-aminoethanol, 2,3butanediol, glucose 6-phosphate, maltotriose, sedoheptulosan, stachyose, D-tagatose, lactamide, 2 'deoxyadenosine, $\alpha$-ketoglutaric acid, propionic acid, succinamic acid, 3-methylglucose, bromosuccinic acid, glucuronamide, D-alanine, L-alanyl glycine, L-asparagine, L-aspartic acid, glycyl-L-aspartic acid, L-histidine, hydroxy-L-proline, L-threonine, DL-carnitine, $\gamma$ aminobutyric acid, uroconic acid, inosine, D-melezitose, malate and trypsin. However, none of the following compounds were used by either strain: Dmannose, lactose, D-trehalose, D-raffinose, glycerol, m-inositol, $\alpha$-cyclodextrin, Tween $80, N$-acetyl-Dgalactosamine, $N$-acetyl-D-glucosamine, gentiobiose, $\alpha$-D-lactose, D-melibiose, monomethylsuccinate, Dgalacturonic acid lactone, D-galacturonic acid, Dgluconic acid, $\alpha$-hydroxybutyric acid, $\beta$-hydroxybutyric acid, $\gamma$-hydroxybutyric acid, $p$-hydroxyphenyl acetic acid, itaconic acid, putrescine, DL- $\alpha$-glycerol phosphate, glucose 1-phosphate, mannan, $N$-acetylmannosamine, methyl $\beta$-D-galactoside, methyl $\alpha$-Dmannoside, $N$-acetyl-L-glutamic acid, adenosine- 5 monophosphate, uridine- $5^{\prime}$-monophosphate, fructose 6-phosphate, $\alpha$-ketovaleric acid, malonic acid, Lproline, L-alanine, L-glutamic acid, glycyl-L-glutamic acid, L-leucine, L-ornithine, L-phenylalanine, Lpyroglutamic acid, uridine, phenylethylamine, inulin, salicin, lactate, serine, DL-lactic acid, citric acid, acetic acid, cis-aconitic acid, $N$-acetylglucosamine, adenine, L-tyrosine, $\alpha$-D-glucose and adonitol.

The enzyme activities detected with the API ZYM 
Table 1. Carbon substrates utilization profiles used to differentiate Ben $107^{\top}$, Ben $108^{\top}$ and $F$. antarctica using the BIOLOG GN and GP Microplate system

+ , Utilized; -, not utilized.

\begin{tabular}{|c|c|c|c|}
\hline Carbon source & Ben $107^{T}$ & F. antarctica & Ben $108^{\mathrm{T}}$ \\
\hline i-Erythritol & + & + & - \\
\hline D-Saccharic acid & + & + & - \\
\hline Formic acid & + & + & - \\
\hline Adonitol & + & + & - \\
\hline L-Rhamnose & - & - & + \\
\hline Maltose & - & - & + \\
\hline Sucrose & - & - & + \\
\hline$\beta$-Cyclodextrin & - & - & + \\
\hline L-Fucose & - & - & + \\
\hline 2-Aminoethanol & - & - & + \\
\hline 2,3-Butanediol & - & - & + \\
\hline Glucose 6-phosphate & - & - & + \\
\hline Maltotriose & - & - & + \\
\hline Sedoheptulosan & - & - & + \\
\hline Stachyose & - & - & + \\
\hline D-Tagatose & - & - & + \\
\hline Lactamide & - & - & + \\
\hline 2'Deoxyadenosine & - & - & + \\
\hline$\alpha$-Ketoglutaric acid & - & - & + \\
\hline Propionic acid & - & - & + \\
\hline Succinamic acid & - & - & + \\
\hline Glucuronamide & - & - & + \\
\hline D-Alanine & - & - & + \\
\hline L-Alanyl-glycine & - & - & + \\
\hline L-Asparagine & - & - & + \\
\hline L-Aspartic acid & - & - & + \\
\hline Glycyl-L-aspartic acid & - & - & + \\
\hline L-Histidine & - & - & + \\
\hline Hydroxy-L-proline & - & - & + \\
\hline L-Threonine & - & - & + \\
\hline DL-Carnitine & - & - & + \\
\hline$\gamma$-Aminobutyric acid & - & - & + \\
\hline Uroconic acid & - & - & + \\
\hline Inosine & - & - & + \\
\hline Malate & - & - & + \\
\hline D-Fructose & + & - & + \\
\hline D-Galactose & + & - & + \\
\hline D-Cellobiose & + & - & + \\
\hline Mannitol & + & - & + \\
\hline Dextrin & + & - & + \\
\hline Methyl $\beta$-D-glucoside & + & - & + \\
\hline D-Psicose & + & - & + \\
\hline Turanose & + & - & + \\
\hline Methyl-pyruvate & + & - & + \\
\hline$\alpha$-Ketobutyric acid & + & - & + \\
\hline Amygdalin & + & - & + \\
\hline Arbutin & + & - & + \\
\hline Methyl $\alpha$-D-galactoside & + & - & + \\
\hline 3-Methyl glucose & - & + & + \\
\hline Palatinose & + & - & + \\
\hline D-Lactic acid methyl ester & + & - & + \\
\hline Pyruvic acid & + & - & + \\
\hline Adenosine & + & - & + \\
\hline Thymidine-5'-monophosphate & + & - & + \\
\hline Quinic acid & + & - & + \\
\hline Bromosuccinic acid & - & + & + \\
\hline Alaninamide & + & - & - \\
\hline L-Proline & - & + & - \\
\hline Thymidine & + & - & - \\
\hline
\end{tabular}




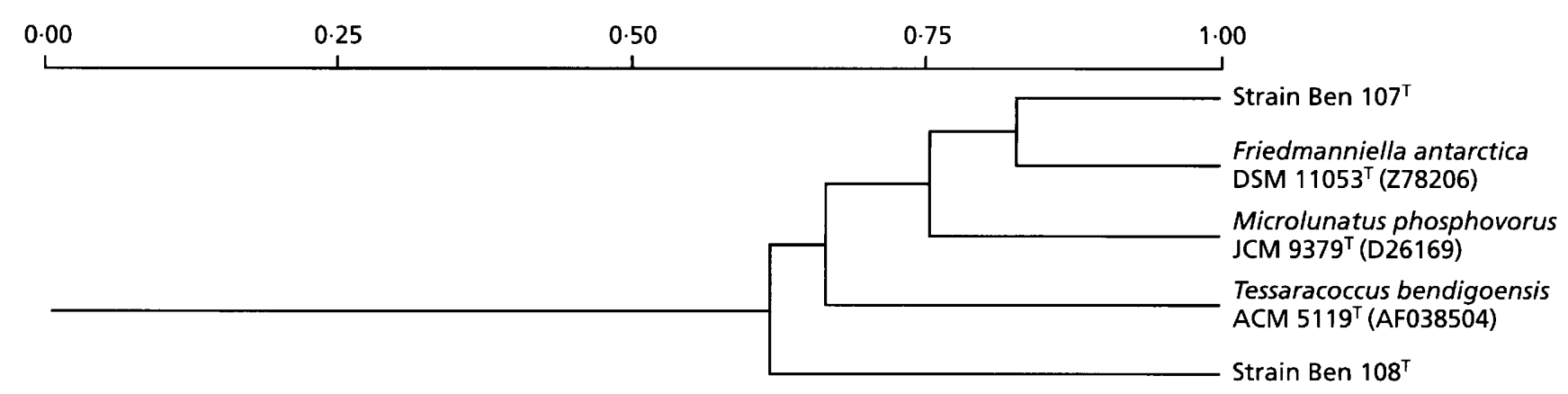

Fig. 4. Dendrogram based on an $S_{S M}$ /UPGMA numerical taxonomy analysis of the phenotypic characteristics of strains Ben $107^{\top}$, Ben $108^{\top}, T$. bendigoensis, M. phosphovorus and $F$. antarctica.

system for both strains Ben $107^{\mathrm{T}}$ and Ben $108^{\mathrm{T}}$ were as follows: alkaline phosphatase, esterase, esterase lipase, lipase, leucine arylamidase, valine arylamidase, cystine arylamidase, acid phosphatase, naphthol-AS-BIphosphohydrolase, $\alpha$-galactosidase, $\beta$-galactosidase, $\alpha$-glucosidase and $\beta$-glucosidase. None of the following enzyme activities were detected for either strain Ben $107^{\mathrm{T}}$ or Ben $108^{\mathrm{T}}$ : chymotrypsin, $\beta$-glucuronidase, $N$-acetyl- $\beta$-glucosaminidase, $\alpha$-mannosidase and $\alpha$ fucosidase. Trypsin activities were only detected in strain Ben $108^{\mathrm{T}}$ and not in strain Ben $107^{\mathrm{T}}$. Lysine decarboxylase, ornithine decarboxylase and arginine dihydrolase activities were not detected with the Microbact 24E system with either strain Ben $107^{\mathrm{T}}$ or strain Ben $108^{\mathrm{T}}$. Both strains Ben $107^{\mathrm{T}}$ and Ben $108^{\mathrm{T}}$ were negative for indole, Voges-Proskauer and threonine deaminase with the Microbact 24E system and did not reduce nitrate to nitrite. Neither gelatin nor casein was hydrolysed. Both strains were catalase- and urease-positive but oxidase-negative. Substrate utilizations and enzymic activities which differed between strain Ben $107^{\mathrm{T}}$, strain Ben $108^{\mathrm{T}}$ and $F$. antarctica are given in Table 1.

Substrate utilization tests in addition to those obtained from BIOLOG GP and GN systems and Microbact 24 were also performed, and the data revealed that strains Ben $107^{\mathrm{T}}$ and Ben $108^{\mathrm{T}}$ could not utilize $p$-hydroxybenzoate, benzoate, disodium succinate, Tween 20,40 and 60 , potassium hydrogen tartrate, adenine and DL-tyrosine. Hypoxanthine, elastin and xanthine were not hydrolysed by either strain Ben $107^{\mathrm{T}}$ or Ben $108^{\mathrm{T}}$. Growth of both strains was inhibited by penicillin (10 IU), crystal violet $(0.001$ and $0.0001 \%$, $\mathrm{w} / \mathrm{v})$, phenol $(0.1$ and $0.3 \%, \mathrm{w} / \mathrm{v})$, phenyl alcohol $(0.03 \%, \mathrm{w} / \mathrm{v})$, sodium azide $(0.1$ and $0.2 \%, \mathrm{w} / \mathrm{v})$ and $\mathrm{NaCl}(5$ and $7 \%, \mathrm{w} / \mathrm{v})$.

Numerical taxonomic analysis performed on all the physiological and biochemical data revealed that strain Ben $107^{\mathrm{T}}$ and $F$. antarctica formed a tight cluster at an $S_{\mathrm{SM}}$ value of 0.82 (Fig. 4) with the UPGMA algorithm [an $S_{\mathrm{SM}}$ value of 0.85 is often used to delineate between species (Sneath, 1978)]. Both strain Ben $107^{\mathrm{T}}$ and $F$. antarctica linked with $M$. phosphovorus at an $S_{\mathrm{SM}}$ value of 0.75 and, in turn, all three strains grouped with $T$. bendigoensis at an $S_{\mathrm{SM}}$ value of 0.67 , also using the UPGMA algorithm (Fig. 4). However, strain Ben $108^{\mathrm{T}}$ only linked with all the other organisms examined at a much lower $S_{\mathrm{SM}}$ of 0.62 (Fig. 4).

\section{DNA-DNA hybridization and DNA base composition}

DNA relatedness, as determined by DNA-DNA hybridization, showed that strain Ben $107^{\mathrm{T}}$ is only $28 \%$ related to $M$. phosphovorus (JCM 9379 ${ }^{\mathrm{T}}$ ), $18 \%$ related to Propioniferax innocua (DSM 8251), $21 \%$ related to $T$. bendigoensis (ACM 5119 ${ }^{\mathrm{T}}$ ) and $50 \%$ related to $F$. antarctica $\left(\mathrm{DSM} 11053^{\mathrm{T}}\right)$. Strain Ben $108^{\mathrm{T}}$ was only $33 \%$ related to $M$. phosphovorus (JCM 9379 ), 22\% related to Propioniferax innocua (DSM 8251 ), $20 \%$ related to $T$. bendigoensis (ACM $5119^{\mathrm{T}}$ ) and $27 \%$ related to $F$. antarctica (DSM $11053^{\mathrm{T}}$ ). However, strains Ben $107^{\mathrm{T}}$ and Ben $108^{\mathrm{T}}$ were only $29 \%$ related to each other. The DNA $\mathrm{G}+\mathrm{C}$ compositions of strains Ben $107^{\mathrm{T}}$ and Ben $108^{\mathrm{T}}$ were 69 and $74 \mathrm{~mol} \%$, respectively.

\section{Phylogenetic analysis}

An almost complete sequence of the 16S rRNA gene for strains Ben $107^{\mathrm{T}}(1469 \mathrm{nt})$ and Ben $108^{\mathrm{T}}(1465 \mathrm{nt})$ corresponding to positions 26-1522 of the Escherichia coli sequence according to the nomenclature of Winker $\&$ Woese (1991) was determined. Phylogeny based on 777 unambiguous bases after 16S rDNA data analysis indicated that both strains Ben $107^{\mathrm{T}}$ and Ben $108^{\mathrm{T}}$ are members of the high-G $+\mathrm{C}$ Gram-positive bacteria of the class Firmicutes in the domain Bacteria. The phylogenetic tree (Fig. 5) shows that strains Ben $107^{\mathrm{T}}$ and Ben $108^{\mathrm{T}}$ form a coherent cluster together with $F$. antarctica and are related to each other at a similarity level greater than $97.0 \%$. Strains Ben $107^{\mathrm{T}}$, Ben $108^{\mathrm{T}}$ and $F$. antarctica are only $96.1,96.9$ and $96.4 \%$ similar, respectively, to $M$. phosphovorus, their closest relative when 777 bases were compared. However, when almost complete sequences (1455 unambiguous bases) 


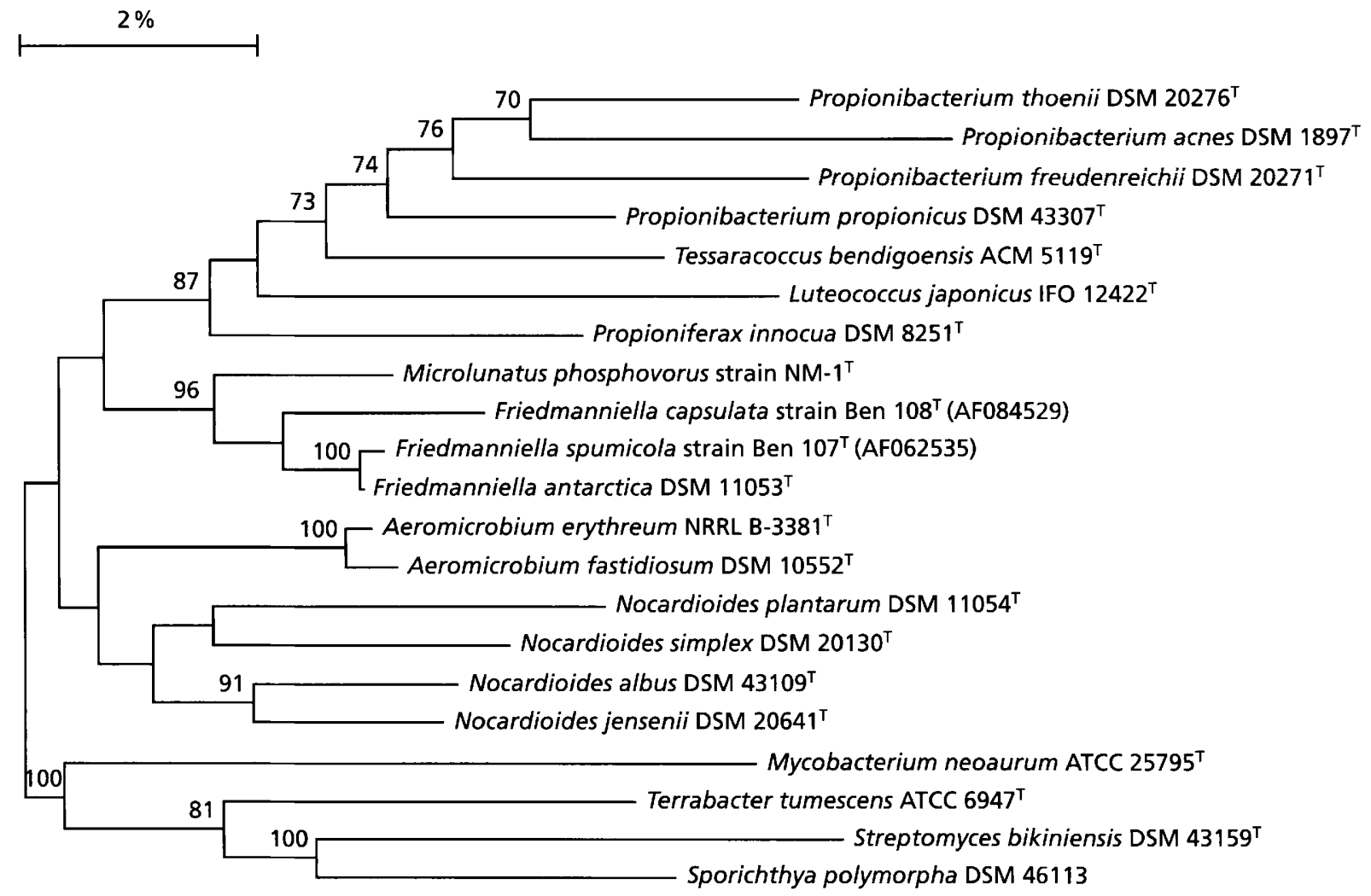

Fig. 5. Phylogenetic position of $F$. spumicola (strain Ben $107^{\top}$ ) and $F$. capsulata (strain Ben $108^{\top}$ ) within the suborder Propionibacterineae of the high-G + C-content Gram-positive bacteria.

Table 2. Cellular fatty acids compositions of Ben $107^{\top}$, Ben $108^{\top}$, Friedmanniella antarctica, Tessaracoccus bendigoensis, Microlunatus phosphovorus, Propioniferax innocua and Luteococcus japonicus

i, Iso; ai, anteiso. Examples of naming fatty acids: $\mathrm{C}_{15: 0}$, pentadecanoic acid; i- $\mathrm{C}_{15: 0^{-}}, 13$-methyltetradecanoic acid; ai- $\mathrm{C}_{15: 0}$, 12methyltetradecanoic acid; $\mathrm{C}_{15: 1}$, cis-9-pentadecenoic acid.

\begin{tabular}{|c|c|c|c|c|c|c|c|c|c|c|c|c|c|c|c|c|c|c|c|c|c|c|}
\hline \multirow[t]{2}{*}{ Strain } & \multicolumn{22}{|c|}{ Cellular fatty acid composition (\%) } \\
\hline & $\mathrm{C}_{13: 1}$ & $\begin{array}{l}\mathrm{i}- \\
\mathrm{C}_{1400}\end{array}$ & $\mathrm{C}_{14: 0}$ & $\mathrm{C}_{14: 1}$ & $\begin{array}{c}\text { i- } \\
\mathrm{C}_{15: 0}\end{array}$ & $\begin{array}{l}\text { ai- } \\
C_{15: 0}\end{array}$ & $\mathrm{C}_{\mathrm{ts:0}}$ & $\begin{array}{c}\text { i- } \\
\mathrm{C}_{15 ; 1}\end{array}$ & $\mathrm{C}_{\mathrm{t}: 1}$ & $\begin{array}{c}i- \\
C_{16: 0}\end{array}$ & $\begin{array}{c}\text { i- } \\
C_{16: 1}\end{array}$ & $C_{16: 0}$ & $\mathrm{C}_{16: 1}$ & $\mathrm{C}_{17: 0}$ & $\mathbf{C}_{17: 1}$ & $\begin{array}{c}\text { i- } \\
C_{17: 0}\end{array}$ & $\begin{array}{c}\text { i- } \\
C_{17: 1}\end{array}$ & $\begin{array}{l}\text { ai- } \\
C_{17: 0}\end{array}$ & $\begin{array}{l}\text { ai- } \\
C_{17: 1}\end{array}$ & $C_{18: 0}$ & $C_{18: 1}$ & $C_{18: 2}$ \\
\hline Ben $108^{\mathrm{T}}$ & 0 & 2.5 & 1.8 & 0 & $13 \cdot 0$ & $58 \cdot 8$ & 0 & 0 & 0 & $4 \cdot 4$ & 0 & $3 \cdot 7$ & 0 & 0 & 0 & $9 \cdot 0$ & 0 & 68 & 0 & 0 & 0 & 0 \\
\hline Ben $107^{\mathrm{T}}$ & 0 & $3 \cdot 9$ & $3 \cdot 3$ & 0 & $13 \cdot 3$ & $57 \cdot 7$ & $3 \cdot 2$ & 0 & 0 & 0 & 0 & 4.5 & 0 & 0 & 0 & 0 & 0 & 0 & 0 & 0 & $14 \cdot 1$ & 0 \\
\hline $\begin{array}{l}\text { Friedmanniella } \\
\text { antarctica }\end{array}$ & 0 & $2 \cdot 3$ & 0 & 0 & $23 \cdot 2$ & $54 \cdot 5$ & 0 & 0 & 0 & $2 \cdot 4$ & 0 & 0 & $2 \cdot 9$ & 0 & 0 & 0 & 0 & 0 & 0 & 0 & 0 & 6.0 \\
\hline $\begin{array}{c}\text { Tessaracoccus } \\
\text { bendigoensis }\end{array}$ & $2 \cdot 0$ & $4 \cdot 1$ & $3 \cdot 1$ & $2 \cdot 0$ & $5 \cdot 0$ & 47.0 & 0 & $3 \cdot 6$ & $6 \cdot 2$ & $4 \cdot 7$ & 3.9 & $5 \cdot 7$ & 0 & 0 & 0 & 0 & $8 \cdot 1$ & 0 & 0 & 0 & 0 & 0 \\
\hline $\begin{array}{l}\text { Microlunatus } \\
\text { phosphovorus }\end{array}$ & 0 & $4 \cdot 0$ & 2.9 & 0 & $22 \cdot 4$ & $43 \cdot 5$ & 0 & 0 & 0 & $6 \cdot 2$ & 0 & $7 \cdot 5$ & 0 & 0 & 0 & 0 & 0 & 0 & 0 & $5 \cdot 6$ & 0 & 0 \\
\hline Propioniferax innocua & 0 & $3 \cdot 2$ & 0 & 0 & $20 \cdot 9$ & 46.5 & 0 & 1.2 & 0 & $7 \cdot 3$ & $4 \cdot 5$ & 0 & 0 & 0 & 0 & $2 \cdot 2$ & $1 \cdot 3$ & $6 \cdot 7$ & $2 \cdot 9$ & 0 & 0 & 0 \\
\hline Luteococcus japonicus & 0 & 0 & $1 \cdot 0$ & 0 & 0 & 0 & 5.6 & 0 & 11.7 & 0 & 0 & 48 & $20 \cdot 5$ & $2 \cdot 4$ & $48 \cdot 1$ & 0 & 0 & 0 & 0 & 0 & 3.2 & 0 \\
\hline
\end{tabular}

for strain Ben $107^{\mathrm{T}}$ and $F$. antarctica were compared, they were found to be $98.5 \%$ similar, whereas strain Ben $108^{\mathrm{T}}$ was 95.9 and $95.8 \%$ similar to $F$. antarctica and strain Ben $107^{\mathrm{T}}$, respectively, on the basis of $16 \mathrm{~S}$ rDNA sequence data. All three are most closely related to $M$. phosphovorus, Luteococcus japonicus, T. bendigoensis, Propionibacterium propionicus and Propioniferax innocua, organisms which are currently placed in the suborder Propionibacterineae (Stackebrandt et al., 1997).

\section{Chemotaxonomic properties}

The cellular fatty acid profile of strain Ben $107^{\mathrm{T}}$ is characterized by the predominance of: ai- $\mathrm{C}_{15: 0}$, 12-methyltetradecanoic acid $(57.7 \%) ; \mathrm{C}_{18: 1}$, octa- 
Table 3. Comparative phenotypic characters of Propioniferax innocua, Propionibacterium propionicus, Luteococcus japonicus, Tessaracoccus bendigoensis, Microlunatus phosphovorus, Friedmanniella antarctica, Ben $107^{\top}$ and Ben $108^{\top}$

Strains: 1, Ben $107^{\mathrm{T}} ; 2$, Ben $108^{\mathrm{T}} ; 3$, Friedmanniella antarctica (data obtained from Schumann et al., 1997); 4, Microlunatus phosphovorus (data obtained from Nakamura et al., 1995); 5, Luteococcus japonicus (data obtained from Tamura et al., 1994); 6, Tessaracoccus bendigoensis (data obtained from Maszenan et al., 1999); 7, Propionibacterium propionicus (data obtained from Charfreitag et al., 1988; Schaal, 1986); 8, Propioniferax innocua (data obtained from Pitcher \& Collins, 1991; Yokota et al., 1994). All isolates are Gram-positive, non-motile, non-spore-forming chemo-organotrophs. v, Variable test result; ND, not determined; $\mathrm{d}, 11-89 \%$ strains are positive.

\begin{tabular}{|c|c|c|c|c|c|c|c|c|}
\hline Phenotypic character & 1 & 2 & 3 & 4 & 5 & 6 & 7 & 8 \\
\hline $\mathrm{O}_{2}$ requirement & Aerobe & Aerobe & Aerobe & Aerobe & $\begin{array}{c}\text { Facultative } \\
\text { anaerobe }\end{array}$ & $\begin{array}{c}\text { Facultative } \\
\text { anaerobe }\end{array}$ & $\begin{array}{c}\text { Facultative } \\
\text { anaerobe }\end{array}$ & $\begin{array}{c}\text { Facultative } \\
\text { anaerobe }\end{array}$ \\
\hline Cell morphology & $\begin{array}{l}\text { Cocci }(0.5-1.4 \mu \mathrm{m}) \\
\text { arranged in packets }\end{array}$ & $\begin{array}{l}\text { Cocci }(0.6-1.2 \mu \mathrm{m}) \\
\text { arranged in packets }\end{array}$ & $\begin{array}{c}\text { Cocci }(0.5-2.2 \mu \mathrm{m}) \\
\text { arranged in packets }\end{array}$ & $\begin{array}{c}\text { Cocci }(0 \cdot 8-2 \cdot 0 \mu \mathrm{m}) \\
\text { arranged singly } \\
\text { and in pairs }\end{array}$ & $\begin{array}{l}\text { Cocci in pairs and } \\
\text { tetrads }(0.7-1.0 \mu \mathrm{m})\end{array}$ & $\begin{array}{c}\text { Cocci }(0 \cdot 5-1 \cdot 1 \mu \mathrm{m}) \\
\text { arranged in tetrads }\end{array}$ & $\begin{array}{l}\text { Pleomorphic rods } \\
(0.2-0.8 \mu \mathrm{m})\end{array}$ & $\begin{array}{l}\text { Pleomorphic rods } \\
(0 \cdot 5-1 \cdot 2 \mu \mathrm{m})\end{array}$ \\
\hline Habitat & $\begin{array}{l}\text { Sewage treatment } \\
\text { plant in Australia }\end{array}$ & $\begin{array}{l}\text { Sewage treatment } \\
\text { plant in Australia }\end{array}$ & Antaretic sandstone & $\begin{array}{l}\text { Sewage treatment } \\
\text { plant in Japan }\end{array}$ & Soil and water & $\begin{array}{l}\text { Sewage treatment } \\
\text { plant in Australia }\end{array}$ & $\begin{array}{c}\text { Human oral cavity } \\
\text { and cervicovaginal } \\
\text { secretion }\end{array}$ & $\begin{array}{c}\text { Human epidermal } \\
\text { surface }\end{array}$ \\
\hline $\begin{array}{l}\text { Optimum growth } \\
\text { temperature }\left({ }^{\circ} \mathrm{C}\right)\end{array}$ & 25 & $20-25$ & 22 & $25-30$ & $26-28$ & 25 & $35-37$ & 37 \\
\hline $\begin{array}{l}\text { Growth temperature } \\
\text { range }\left({ }^{\circ} \mathrm{C}\right)\end{array}$ & $15-37$ & $20-25$ & $9 \cdots 25$ & $5-35$ & $12-38$ & $20-37$ & $30-37$ & $10-40$ \\
\hline Optimum growth $\mathrm{pH}$ & $7 \cdot 0-7 \cdot 5$ & $6 \cdot 5-7 \cdot 0$ & $6 \cdot 0-7 \cdot 2$ & $7 \cdot 0$ & ND & $7 \cdot 5$ & ND & $7 \cdot 0$ \\
\hline Growth $\mathrm{pH}$ range & $5 \cdot 5-8 \cdot 0$ & $5 \cdot 5-7 \cdot 5$ & $5 \cdot 1-8 \cdot 7$ & $5 \cdot 0-9 \cdot 0$ & ND & $5 \cdot 5-9 \cdot 3$ & & $\mathrm{Nl})$ \\
\hline $\begin{array}{l}\text { Presence of } \\
\text { metachromatic } \\
\text { granules* }\end{array}$ & $+\uparrow$. PolyP & $+\uparrow$, PolyP & $+\uparrow$. PolyP &,+ PolyP & ND &,+ PolyP & ND & $\begin{array}{l}+, \text { type of storage } \\
\text { granules unknown }\end{array}$ \\
\hline Oxidase & - & - & - & + (weak) & + & - & ND & + \\
\hline Catalase & + & + & $+\ddagger$ & + & + & + & - & + \\
\hline Production of indole & - & - & - & + & - & - & - & - \\
\hline Production of $\mathrm{H}_{2} \mathrm{~S}$ & + & + & + & ND & - & - & + & - \\
\hline Major menaquinone & $\begin{array}{c}\text { MK-9 }\left(\mathrm{H}_{4}\right), \text { MK- } \\
7\left(\mathrm{H}_{2}\right)\end{array}$ & $\begin{array}{c}\left.\text { MK-9( } \mathrm{H}_{4}\right), \text { MK- } \\
9\left(\mathrm{H}_{4}\right) \text { and MK- } \\
7\left(\mathrm{H}_{4}\right)\end{array}$ & MK-9(- $\left.\mathrm{H}_{4}\right)$ & MK- $9\left(\mathrm{H}_{4}\right)$ & MK- $-9\left(\mathrm{H}_{4}\right)$ & $\begin{array}{c}\text { MK- } 9\left(\mathrm{H}_{4}\right) \text { and MK- } \\
7\left(\mathrm{H}_{4}\right)\end{array}$ & MK-9( $\left(\mathrm{H}_{4}\right)$ & MK $-9\left(\mathrm{H}_{4}\right)$ \\
\hline $\begin{array}{l}\text { Diamino } \\
\text { acid/murein type }\end{array}$ & $\mathrm{LL}-\mathrm{A}_{2} \mathrm{Pm} \mathrm{A} 3 \gamma^{\prime}$ & $\mathrm{LL}-\mathrm{A}_{2} \mathrm{pm} \mathrm{A} 3 \gamma^{\prime}$ & $\mathrm{LL}-\mathrm{A}_{2} \mathrm{pm} \mathbf{A} 3 \gamma^{\prime}$ & $\mathrm{LL}-\mathrm{A}_{2} \mathrm{pm} \mathrm{A} 3 \gamma^{\prime} \S$ & $\mathbf{L L}-\mathbf{A}_{2} \mathrm{pm} \mathrm{A} 3 \gamma$ & $\mathrm{LL}-\mathrm{A}_{2} \mathrm{pm} \mathrm{A} 3 \gamma^{\prime}$ & $\mathrm{LL}-\mathrm{A}_{2} \mathrm{pm} \mathrm{A} 3 \gamma^{\prime}$ & LL-A. $\mathrm{pm}$ A $3 \gamma$ \\
\hline Polar lipid\| & $\begin{array}{c}\text { PI, PG, DPG, PL, } \\
\text { GL }\end{array}$ & $\begin{array}{c}\mathrm{Pl}, \mathrm{PG}, \mathrm{DPG}, \mathrm{PL}, \\
\text { GL }\end{array}$ & PI, PG, DPG, PL & PI, PG, DPG, PL & DPG, PG, PI, GL & PI, PG, DPG, PL & ND & PE, PG, PL, GL\$ \\
\hline Urease & + & + & + & ++ & - & - & - & + \\
\hline Nitrate reduction & - & - & $-\S$ & $+\ddagger$ & - & + & + & + \\
\hline $\mathrm{G}+\mathrm{C}(\mathrm{mol} \%)$ & 69 & 74 & 73 & 68 & $66-68$ & 74 & $63-65$ & $59-63$ \\
\hline \multicolumn{9}{|l|}{$\begin{array}{l}\text { Carbohydrates } \\
\text { utilized: }\end{array}$} \\
\hline Lactose & - & - & - & -+ & ND & + & d & - \\
\hline Raffinose & - & - & - & $-\ddagger$ & + & + & + & - \\
\hline Mannitol & + & - & - & ++ & + & + & + & - \\
\hline Glycerol & - & - & - & $-\ddagger$ & + & + & d & + \\
\hline Arabinose & + & + & + (weak) & $+\ddagger$ & $\begin{array}{l}\text { + for D-arabinose } \\
\text { - for L-arabinose }\end{array}$ & + & - & - \\
\hline Inositol & - & - & - & $+\ddagger$ & + & - & $\mathrm{d}$ & - \\
\hline Sucrose & - & + & - & $-\ddagger$ & + & + & + & + \\
\hline Fructose & + & + & - & $-\ddagger$ & + & + & + & + \\
\hline Glucose & - & - & - & $-\ddagger$ & + & + & + & + \\
\hline Mannose & - & - & - & $-\ddagger$ & + & + & $\mathrm{d}$ & + \\
\hline Galactose & + & - & - & $-\ddagger$ & + & + & $d$ & V \\
\hline Trehalose & - & - & - & $-\ddagger$ & + & - & $\mathrm{d}$ & + \\
\hline Maltose & - & + & - & $-z$ & + & + & + & + \\
\hline Ribose & + & + & + & $+\ddagger$ & + & + & $d$ & ND \\
\hline Xylose & + & + & + (weak) & $-\ddagger$ & - & + & - & ND \\
\hline Rhamnose & - & + & - & $-\ddagger$ & - & - & - & - \\
\hline Adonitol & - & - & - & $-\ddagger$ & ND & - & $\mathrm{d}$ & - \\
\hline
\end{tabular}

*Presence of metachromatic granules, Microlunatus, Tessaracoccus, Friedmanniella and strain Ben $107^{\mathrm{T}}$ contain PolyP granules, the granule type for Propioniferax innocua has not been determined.

$\dagger$ Data obtained in this study.

$\ddagger$ Result obtained by BIOLOG and Microbact 24E (A. M. Maszenan and others, unpublished results).

$\S$ Data obtained from Schumann et al. (1997).

|| Abbreviations: PE, phosphatidyl ethanolamine; PG, phosphatidyl glycerol; PL, unidentified phospholipid (s); GL, unidentified glycolipid (s); PI, phosphatidyl inositol and DPG, diphosphatidyl glycerol.

- Tested for Microlunatus phosphovorus and Tessaracoccus bendigoensis under aerobic conditions. 
decenoic acid (14.1\%); and $\mathrm{i}-\mathrm{C}_{15: 0}, 13$-methyltetradecanoic acid (13.3\%). Unbranched fatty acids with 14,15 and 16 carbon atoms were found in trace amounts (Table 2). Five isoprenoid quinones MK9( $\left.\mathrm{H}_{4}\right)$, MK-7 $\left(\mathrm{H}_{2}\right)$, MK-8( $\left.\mathrm{H}_{2}\right)$, MK-9 $\left(\mathrm{H}_{2}\right)$ and MK$8\left(\mathrm{H}_{4}\right)$ with the following ratio of $62: 11: 7: 6: 4$ were observed. The peptidoglycan of strain Ben $107^{\mathrm{T}}$ contained LL-A $\mathrm{pm}_{2}$ and its interpeptide bridge had a single glycine residue and position 1 of the peptide subunit is occupied by glycine, properties which are characteristic of the type A3 $\gamma^{\prime}$ peptidoglycan (Schleifer \& Seidl, 1985). The polar lipid profiles of strains Ben $107^{\mathrm{T}}$ and Ben $108^{\mathrm{T}}$ are similar as both contained phosphatidyl inositol, phosphatidyl glycerol, diphosphatidyl glycerol and two unidentified glycolipids and phospholipids as shown in Table 3. Strain Ben $108^{\mathrm{T}}$ also had the type $\mathrm{A} 3 \gamma^{\prime}$ peptidoglycan with LL- $\mathrm{A}_{2} \mathrm{pm}$ and glycine moiety occupying position 1 , but its respiratory menaquinones differed from those of strain Ben $107^{\mathrm{T}}$, as it possesses $\mathrm{MK}-7\left(\mathrm{H}_{4}\right)$ in addition to $\mathrm{MK}-9\left(\mathrm{H}_{4}\right)$ and $\mathrm{MK}-9\left(\mathrm{H}_{2}\right)$, in the following ratio of 8:72:10, and lacks MK-8( $\left.\mathrm{H}_{2}\right)$ and MK-8( $\left.\mathrm{H}_{4}\right)$. The cellular fatty acid profile of strain Ben $108^{\mathrm{T}}$ is similar to that of strain Ben $107^{\mathrm{T}}$ with ai- $\mathrm{C}_{15: 0}, 12$-methyltetradecanoic acid $(58.8 \%)$, as the dominant fatty acid. However, differences were also observed between them as shown in Table 2.

\section{DISCUSSION}

Strains Ben $107^{\mathrm{T}}$ and Ben $108^{\mathrm{T}}$, both isolated from activated sludge, and $F$. antarctica are all non-motile, oxidase-negative, orange-pigmented, slow-growing, Gram-positive cocci, appearing as aggregates of cells. These aggregates become layered, probably as cell division occurs in more than one plane, and the cells are embedded in capsular material, which is particularly extensive with strain Ben $108^{\mathrm{T}}$. Strain Ben $107^{\mathrm{T}}$ and $F$. antarctica, the only currently described member of the genus Friedmanniella (Schumann et al., 1997), share very similar biochemical and physiological characteristic, despite being isolated from totally different habitats. Strain Ben $108^{\mathrm{T}}$ differs considerably in its phenotype from these two organisms (Fig. 4).

However, 16S rDNA sequence data show that strains Ben $107^{\mathrm{T}}$ and Ben $108^{\mathrm{T}}$ and $F$. antarctica all cluster at a high $(>97 \%)$ similarity level, in the high-G $+\mathrm{C}$ group of Gram-positive bacteria. These sequence data would suggest that strains Ben $107^{\mathrm{T}}$ and Ben $108^{\mathrm{T}}$ are not members of the genera Propionibacterium (Schaal et al., 1986; Charfreitag et al., 1988), Propioniferax (as Propioniferax innocua) (Pitcher \& Collins, 1991; Yokota et al., 1994), Luteococcus (Tamura et al., 1994) or Tessaracoccus (Maszenan et al., 1999), even though they share many chemotaxonomic properties in common with some of them (Table 3). The nearest relative to strains Ben $107^{\mathrm{T}}$ and Ben $108^{\mathrm{T}}$ and $F$. antarctica based on 16S rDNA sequence data is $M$. phosphovorus clustering at a similarity level only slightly below $97 \%$, illustrating how closely related these four organisms are to each other. In fact, strain Ben $108^{\mathrm{T}}$ is closer to $M$. phosphovorus than to either Ben $107^{\mathrm{T}}$ or $F$. antarctica when DNA hybridization values are considered.

Allowing that the separation of Microlunatus and Friedmanniella into different genera is justifiable, the decision then has to be made as to which of these two genera do Ben $107^{\mathrm{T}}$ and Ben $108^{\mathrm{T}}$ best belong. The recognition that Friedmanniella should be separated from Microlunatus was based on several criteria including their 16S rDNA structures, morphological and physiological characteristic and chemotaxonomic features (Schumann et al., 1997). If only cell arrangement, cell pigmentation and culture growth rate (Schumann et al., 1997) are taken into account, then strains Ben $107^{\mathrm{T}}$ and Ben $108^{\mathrm{T}}$ are clearly more closely related to Friedmanniella than Microlunatus. Furthermore, strains Ben $107^{\mathrm{T}}$ and Ben $108^{\mathrm{T}}$ and $F$. antarctica are all oxidase-negative while $M$. phosphovorus is oxidase-positive. In fact, strain Ben $107^{\mathrm{T}}$ is most similar to Friedmanniella in all the characteristics described here and there is little doubt that it should be included in this genus. Both strain Ben $107^{\mathrm{T}}$ and $F$. antarctica also have G-T at position 602-636, while $M$. phosphovorus, the only known Microlunatus species, has A-T (Table 4).

However, there are enough differences between strain Ben $107^{\mathrm{T}}$ and $F$. antarctica to indicate that they are different species of the genus Friedmanniella. These differences include the additional occurrence of MK$7\left(\mathrm{H}_{2}\right)$, MK-8 $\left(\mathrm{H}_{2}\right)$ and MK-8 $\left(\mathrm{H}_{4}\right)$ in strain Ben $107^{\mathrm{T}}$, together with two unidentified glycolipids and one unidentified phospholipid, which are not found in $F$. antarctica (Table 3). This view is given additional support by differences in cellular fatty acid compositions (Table 4); strain Ben $107^{\mathrm{T}}$ contains $\mathrm{C}_{14: 0}, \mathrm{C}_{15: 0}, \mathrm{C}_{16: 0}$ and $\mathrm{C}_{18: 1}$, while $F$. antarctica has $\mathrm{i}-$ $\mathrm{C}_{16: 0}, \mathrm{C}_{16: 1}$ and $\mathrm{C}_{18: 2}$. Furthermore, the DNA-DNA hybridization value of $<70 \%$ homology between them confirms they are not members of a single genomic species (Wayne et al., 1987; Stackebrandt \& Goebel, 1994). Such a low DNA-DNA homology is unusual, but not unknown in bacteria having high 16S rDNA sequence similarity values (Fox et al., 1992). Hence, we propose that strain Ben $107^{\mathrm{T}}$ be placed in the genus Friedmanniella as a new species, Friedmanniella spumicola.

The fate of strain Ben $108^{\mathrm{T}}$ is more problematic because it seems to fit almost equidistantly between Friedmanniella and Microlunatus and, although the phylogenetic data support its inclusion as a member of the genus Friedmanniella, this claim is harder to justify than with strain Ben $107^{\mathrm{T}}$, when the rest of its properties are considered. Large differences in chemotaxonomic properties, and low DNA-DNA hybridization values between strain Ben $108^{\mathrm{T}}$ and both strain Ben $107^{\mathrm{T}}$ and $F$. antarctica, confirm that strain Ben $108^{\mathrm{T}}$ is not a member of either of these two species. 
Table 4. 165 rDNA nucleotide signatures for Ben $107^{\top}$, Ben $108^{\top}$, Friedmanniella antarctica, and members of the families Propionibacteriaceae and Nocardioidaceae within the suborder Propionibacterineae (Stackebrandt et al., 1997)

Important differences in the signature nucleotides are highlighted in bold and underlined.

\begin{tabular}{|c|c|c|c|c|c|c|c|}
\hline Position* & Propionibacteriaceae & Nocardioidaceae & Ben $107^{\top}$ & Ben $108^{\mathrm{T}}$ & Friedmanniella antarctica & Microlunatus phosphovorus & Tessaracoccus bendigoensis \\
\hline $66-103$ & A-T & $\mathrm{G}-\mathrm{C}$ & A-T & $A-T$ & $A-T$ & $A-T$ & $A-T$ \\
\hline 328 & $\mathrm{~T}$ & $\mathrm{C}$ & $\mathrm{T}$ & $\mathrm{T}$ & $\mathrm{T}$ & $\mathrm{T}$ & $\mathrm{T}$ \\
\hline $370-391$ & $\mathrm{C} \cdot \mathrm{G}$ & $\mathrm{G}-\mathrm{C}$ & $\mathrm{C}-\mathrm{G}$ & $\mathrm{C}-\mathrm{G}$ & $\mathrm{C}-\mathrm{G}$ & $C-G$ & $\mathrm{C}-\mathrm{G}$ \\
\hline $407-435$ & $\mathrm{C}-\mathrm{G}$ & A-T & $\mathrm{C}-\mathrm{G}$ & $\mathrm{C}-\mathrm{G}$ & $\mathrm{C}-\mathrm{G}$ & $\mathrm{C}-\mathrm{G}$ & $\mathrm{C}-\mathrm{G}$ \\
\hline $602-636$ & A-T & $\mathrm{G}-\mathrm{T}$ & G-T & A-T & $\underline{G}-\mathbf{T}$ & $A-T$ & $\mathrm{G}-\mathrm{T}$ \\
\hline $658-748$ & $A-T$ & $\mathrm{~T}-\mathrm{A}$ & $\overline{\mathbf{G}-\mathbf{A}}$ & $\underline{\mathbf{G}-\mathbf{A}}$ & $\overline{\mathbf{G}-\mathbf{A}}$ & $A-T$ & $A-T$ \\
\hline 686 & $\mathrm{G}$ & $\mathrm{T}$ & $\overline{\mathrm{G}}$ & $\bar{G}$ & $G$ & $\mathrm{G}$ & A \\
\hline 780 & A & $\mathrm{G}$ & A & A & A & $\mathrm{A}$ & $\mathrm{A}$ \\
\hline 787 & $\mathrm{C}$ & A & $\mathrm{C}$ & $\mathrm{C}$ & $\mathrm{C}$ & $\mathrm{C}$ & $\mathrm{C}$ \\
\hline 819 & $\mathrm{G}$ & $\mathrm{T}$ & $\mathrm{G}$ & $\mathrm{G}$ & G & $\mathrm{G}$ & G \\
\hline $825-875$ & $A-T$ & $\mathrm{G}-\mathrm{C}$ & $A-T$ & $A-T$ & $A-T$ & $A-T$ & $A-T$ \\
\hline $1409-1491$ & $A-T$ & $\mathrm{C}-\mathrm{G}$ & $A-T$ & $A-T$ & $A-T$ & $A-T$ & $A-T$ \\
\hline
\end{tabular}

*E. coli numbering positions for 16S rDNA base sequences after Winker \& Woese (1991).

Thus, the additional presence of $\mathrm{MK}-7\left(\mathrm{H}_{4}\right)$ together with a cellular fatty acid profile containing $\mathrm{i}-\mathrm{C}_{17: 0}$ and ai- $C_{17: 0}$ in strain Ben $108^{\mathrm{T}}$ separates it from both strains Ben $107^{\mathrm{T}}$ and $F$. antarctica. Furthermore, the low $S_{\mathrm{SM}}$ level at which Ben $108^{\mathrm{T}}$ groups with the other two after numerical taxonomic analysis (Fig. 4) would support this separation. Unfortunately, the signature nucleotide positions do not help resolve its taxonomic position. Sharing G-A at position $658-748$ with strain Ben $107^{\mathrm{T}}$ and $F$. antarctica, where $M$. phosphovorus has A-T at these positions, strain Ben $108^{\mathrm{T}}$ together with M. phosphovorus has A-T at position 602-636, while strain Ben $107^{\mathrm{T}}$ and $F$. antarctica both possess G-T (Table 4). No other member of the family Propionibacteriaceae shows this pattern.

In summary, it is felt that the taxonomic structures of this group, and the final position of strain Ben $108^{\mathrm{T}}$ within it, will become clearer only with the isolation of other phylogenetically related strains. The phylogenetic data would, in our opinion, not support the idea that strain Ben $108^{\mathrm{T}}$ is a new species of Microlunatus despite having the highest DNA homology with it or that it belongs to the genus Tessaracoccus (Maszenan et al., 1999) despite its phenotypic similarities to both (Fig. 4), or that it should be placed in a new genus. Our view is that strain Ben $108^{\mathrm{T}}$ is best placed, albeit uneasily, in the genus Friedmanniella as a novel species Friedmanniella capsulata.

Currently, all of the genera mentioned above are in the family Propionibacteriaceae which, together with the family Nocardioidaceae, is in the suborder Propionibacterineae (Stackebrandt et al., 1997). This classification was proposed solely on the presence of signature nucleotides in the $16 \mathrm{~S}$ rDNA (see Table 4) and often families were based on a single characterized isolate (e.g. Microsphaeraceae). Strains Ben $107^{\mathrm{T}}$, Ben $108^{\mathrm{T}}$ and $F$. antarctica have nucleotide signatures which differ from those proposed by Stackebrandt et al. (1997) for delineating the family Propionibacteriaceae, although not those suggested as diagnostic for the suborder Propionibacterineae. Strain
Ben $107^{\mathrm{T}}$ and $F$. antarctica alone have G-A instead of A-T at positions 658-748. However, as mentioned earlier, strain Ben $108^{\mathrm{T}}$ has $\mathrm{A}-\mathrm{T}$ at position $602-636$, which is also shared by Microlunatus species and members of the currently recognized family Propionibacteriaceae as proposed by Stackebrandt et al. (1997), but which is not found in either strain Ben $107^{\mathrm{T}}, F$. antarctica or $T$. bendigoensis. It seems probable that as more strains of these high-G + C Gram-positive bacteria are isolated and characterized, more discrepancies with their nucleotide signatures will become apparent and the scheme of Stackebrandt et al. (1997) will require substantial modification. Until more strains of the genus Friedmanniella are isolated and the diversity of their 16S rDNA nucleotide composition better understood, it might be argued that they could be removed from the currently described family Propionibacteriaceae, despite their very high phenotypic similarities to the other genera currently within this family. However, as they all share high levels of phylogenetic similarity, it could also be argued that they should all stay with the other genera discussed above, within the same family. Other genomic fingerprinting methods need to be applied in order to resolve their intergeneric relationships.

Finally, the ecological diversity of members of the genus Friedmanniella could be considerable since both strains Ben $107^{\mathrm{T}}$ and Ben $108^{\mathrm{T}}$ were isolated from activated sludge foam while $F$. antarctica originated from Antarctic sandstone. Interestingly, $F$. antarctica is reported not to grow in a laboratory below $6{ }^{\circ} \mathrm{C}$ (Schumann et al., 1997), an unexpected finding if its true natural habitat is extreme cold. Some Grampositive bacteria with high- $\mathrm{G}+\mathrm{C}$ content have been implicated to play a major role in biological phosphorus removal (Bond et al., 1995; Wagner et al., 1994). The recent description of Tessaracoccus bendigoensis (Maszenan et al., 1999), which like $F$. spumicola and $F$. capsulata was shown to accumulate PolyP aerobically, would increase the known complexity of organisms which might be responsible for 
biological phosphorus removal in activated sludge. The isolation of strains Ben $107^{\mathrm{T}}$ and Ben $108^{\mathrm{T}}$ from activated sludge and their ability to accumulate PolyP might indicate that they may also play an important role in EBPR activated sludge systems.

\section{Description of Friedmanniella spumicola sp. nov.}

Friedmanniella spumicola (spu.mi'co.la. L. fem. $\mathrm{n}$. spuma foam; L. suffix - cola inhabitant of; M.L. masc./fem. N. spumicola inhabitant of foam).

Cells adhere to one another and form aggregates of four and eight. Growth in liquid and solid media is slow and poor requiring up to 2 weeks. Colony colour when grown on solid and liquid media is dark yellow to pale orange. The temperature range for growth is $15-37^{\circ} \mathrm{C}$ with an optimum temperature of $25^{\circ} \mathrm{C}$. The $\mathrm{pH}$ range over which growth occurs is $5 \cdot 5-8 \cdot 0$, with an optimum $\mathrm{pH}$ of $7 \cdot 0-7 \cdot 5$. Cells store PolyP granules aerobically. It can utilize the following substrates: i-erythritol, D-saccharic acid, formic acid, D-galactose, turanose, methylpyruvate, $\alpha$-ketobutyric acid, alaninamide and thymidine. The following substrates were not utilized: L-rhamnose, maltose, sucrose, $\beta$-cyclodextrin, L-fucose, 2-aminoethanol, 2,3butanediol, glucose 6-phosphate, maltotriose, sedoheptulosan, stachyose, D-tagatose, lactamide, $2^{\prime}$ deoxyadenosine, $\alpha$-ketoglutaric acid, propionic acid, succinamic acid, glucuronamide, D-alanine, L-alanyl-glycine, L-asparagine, L-aspartic acid, glycyl-L-aspartic acid, L-histidine, hydroxy-L-proline, L-threonine, DLcarnitine, $\gamma$-aminobutyric acid, uroconic acid, inosine, D-melezitose, malate, 3-methylglucose, bromosuccinic acid and trypsin. It is also characterized by the presence of $\mathrm{C}_{18: 1}$ (octadecenoic acid; $14.1 \%$ ) and $\mathrm{i}-\mathrm{C}_{15: 0}$ (13methyltetradecanoic acid; $13 \cdot 3 \%$ ). Unbranched fatty acids with 14, 15 and 16 carbons were found in trace amounts. Its major menaquinones are $\mathrm{MK}-9\left(\mathrm{H}_{4}\right)$ and MK-7 $\left(\mathbf{H}_{2}\right)$, with MK-9 $\left(\mathrm{H}_{2}\right)$, MK-8 $\left(\mathrm{H}_{2}\right)$, MK- $8\left(\mathrm{H}_{4}\right)$, present in trace amounts. It possesses $\mathrm{G}-\mathrm{A}$ and $\mathrm{G}-\mathrm{T}$ at positions $658-748$ and $602-636$, respectively. The $\mathrm{G}+\mathrm{C}$ content is about $69 \mathrm{~mol} \%$. Mycolic acids are absent. The cell diameter is $0 \cdot 5-1 \cdot 4 \mu \mathrm{m}$. It originates from activated sludge. The type strain, strain Ben $107^{\mathrm{T}}$, has been deposited in the Australian Collection of Microorganisms, as strain ACM 5121 ${ }^{\mathrm{T}}$.

\section{Description of Friedmanniella capsulata sp. nov.}

Friedmanniella capsulata (cap.su.la'ta. L. fem. adj. capsulata capsulated).

This species is characterized by a bright orange colour when grown in both solid and liquid media. It also can store polyphosphate aerobically. The optimum growth temperature is $20-25^{\circ} \mathrm{C}$. The $\mathrm{pH}$ range for growth is $5 \cdot 5-7 \cdot 5$, with an optimal growth $\mathrm{pH}$ of $6 \cdot 5-7 \cdot 0$. It utilizes L-rhamnose, maltose, sucrose, $\beta$-cyclodextrin, L-fucose, 2-aminoethanol, 2,3-butanediol, glucose 6phosphate, maltotriose, sedoheptulosan, stachyose, Dtagatose, lactamide, 2 'deoxyadenosine, $\alpha$-ketoglutaric acid, propionic acid, succinamic acid, 3-methylglucose, bromosuccinic acid, glucuronamide, D-alanine, L-alanyl glycine, L-asparagine, L-aspartic acid, glycyl-Laspartic acid, L-histidine, hydroxy-L-proline, L-threonine, DL-carnitine, $\gamma$-aminobutyric acid, uroconic acid, inosine, D-melezitose, malate and trypsin. The following substrates are not utilized: i-erythritol, Dsaccharic acid, formic acid, adonitol, D-galactose, Dpsicose, turanose, methyl-pyruvate, $\alpha$-ketobutyric acid, alaninamide and thymidine. Cell diameter is $0 \cdot 6-1 \cdot 2 \mu \mathrm{m}$. Cellular fatty acids are characterized by the presence of $\mathrm{i}-\mathrm{C}_{16: 0}$ (14-methylpentadecanoic acid), $\mathrm{i}_{-} \mathrm{C}_{17: 0}$ (15-methylhexadecanoic acid) and ai- $\mathrm{C}_{17: 0}(14-$ methylhexadecanoic acid). It also contains $\mathrm{MK}-9\left(\mathrm{H}_{4}\right)$ and MK-9 $\left(\mathrm{H}_{2}\right)$ and is characterized by the presence of MK-7 $\left(\mathrm{H}_{4}\right)$. The $\mathrm{G}+\mathrm{C}$ content is $74 \mathrm{~mol} \%$. Mycolic acids are absent. It originates from activated sludge. The type strain, strain Ben $108^{\mathrm{T}}$, has been deposited in the Australian Collection of Microorganisms, as strain ACM $5120^{\mathrm{T}}$.

\section{ACKNOWLEDGEMENTS}

A.M.M. was funded by a LUPRS and OPRS scholarship. This work was supported by a La Trobe University Central Grant and an ARC small grant. We thank Dr H. M. Stratton for assistance with the electron microscopy and $\mathrm{Dr}$ T. C. Burton and Professor H. Trüper for help with naming these isolates.

\section{REFERENCES}

Blackall, L. L., Rossetti, S., Christensson, C., Cunningham, M., Hartman, P., Hugenholtz, P. \& Tandoi, V. (1997). The characterization and description of representatives of ' $G$ ' bacteria from activated sludge plants. Lett Appl Microbiol 25, 63-69.

Bond, P. L., Hugenholtz, P., Keller, J. \& Blackall, L. L. (1995). Bacterial community structures of polyphosphate-removing and non-phosphate-removing activated sludges from sequencing batch reactors. Appl Environ Microbiol 61, 1910-1916.

Bond, P. L., Keller, J. \& Blackall, L. L. (1997). Bio-P and Non-BioP Bacteria identification by a novel microbial approach. In Proceedings of the 3rd Australian Biological Nutrient Removal Conference, Brisbane, Australia, pp. 25-32. Australian Water and Wastewater Association.

Buck, J. D. (1982). Non-staining (KOH) method for determination of Gram reactions of marine bacteria. Appl Environ Microbiol 44, 992-993.

Carucci, A., Majone, M., Ramadori, R. \& Rossetti, S. (1994). Dynamics of phosphorus and organic substrates in anaerobic and aerobic phases of a sequencing batch reactor. Water Sci Technol 30, 237-246.

Cech, J. S. \& Hartman, P. (1993). Competition between polyphosphate and polysaccharide accumulating bacteria in enhanced biological phosphate removal systems. Water Res 27, 1219-1225.

Charfreitag, O., Collins, M. D. \& Stackebrandt, E. (1988). Reclassification of Arachnia propionica as Propionibacterium propionicus comb. nov. Int J Syst Bacteriol 38, 354-357.

De Ley, J., Cattoir, H. \& Reynaerts, A. (1970). The quantitative 
measurement of DNA hybridization from renaturation rates. Eur J Biochem 12, 133-142.

Fox, G. E., Wisotzkey, J. D. \& Jurtshuk, P., Jr (1992). How close is close: 16S rRNA sequence identity may not be sufficient to guarantee species identity. Int J Syst Bacteriol 42, 166-170.

Goodfellow, M. (1971). Numerical taxonomy of some Nocardioform bacteria. J Gen Microbiol 69, 33-80.

Goodfellow, M. \& Pirouz, T. (1982). Numerical classification of Sporoactinomycetes containing meso-diaminopimelic acid in the cell wall. J Gen Microbiol 128, 503-527.

Graham, L. L. (1992). Freeze-substitution studies of bacteria. Electron Microsc Rev 5, 77-103.

Hucker, G. J. (1921). A new modification and application of the Gram stain. J Bacteriol 6, 396-397.

Huss, V. A. R., Festl, H. \& Schleifer, K.-H. (1983). Studies on the spectrophotometric determination of DNA hybridization from renaturation rates. Syst Appl Microbiol 4, 184-192.

Jahnke, K.-D. (1992). BASIC computer program for evaluation of spectroscopic DNA renaturation data from GILFORD SYSTEM 2600 spectrophotometer on a PC/XT/AT type personal computer. J Microbiol Methods 15, 61-73.

Kataoka, N., Tokiwa, Y., Tanaka, Y., Takeda, K. \& Suzuki, T. (1996). Enrichment culture and isolation of slow growing bacteria. Appl Microbiol Biotechnol 45, 771-777.

Knight, G. C., Seviour, E. M., Seviour, R. J., Soddell, J. A., Lindrea, K. C., Strachan, W., De Grey, B. \& Bayly, R. C. (1995). Development of the microbial community of a full scale nutrient removal activated sludge plant during start up. Water Res $\mathbf{2 9}$, 2085-2093.

Lindsay, M. R., Webb, R. I. \& Fuerst, J. A. (1997). Pirellulosomes: a new type of membrane-bounded compartment in planctomycete bacteria of the genus Pirellula. Microbiology 143, 739-748.

Liu, W.-T., Mino, T., Nakamura, K. \& Matsuo, T. (1996). Glycogen accumulating population and its anaerobic substrates uptake in anaerobic-aerobic activated sludge without biological phosphorus removal. Water Res 30, 75-82.

Maidak, B. L., Olsen, G. J., Larsen, N., Overbeek, R., McCaughey, M. J. \& Woese, C. R. (1996). The Ribosomal Database Project (RDP). Nucleic Acids Res 24, 82-85.

Maszenan, A. M., Seviour, R. J., Patel, B. K. C., Rees, G. N. \& McDougall, B. M. (1997). Amaricoccus gen. nov., a Gramnegative coccus occurring in regular packages or tetrads isolated from activated sludge biomass, and descriptions of Amaricoccus veronensis sp. nov., Amaricoccus tamworthensis sp. nov., Amaricoccus tamworthensis sp. nov. and Amaricoccus kaplicensis sp. nov. Int J Syst Bacteriol 47, 727-734.

Maszenan, A. M., Seviour, R. J., Patel, B. K. C., Schumann, P. \& Rees, G. N. (1999). Tessaracoccus bendigoensis gen. nov., sp. nov., a Gram-positive coccus occurring in regular packets or tetrads, isolated from activated sludge biomass. Int $J$ Syst Bacteriol 49, 459-468.

Matsuo, Y. (1994). Effect of the anaerobic solid retention time on enhanced biological phosphorus removal. Water Sci Technol 30, 193-202.

Matsuzawa, Y. \& Mino, T. (1991). Role of glycogen as an intracellular carbon reserve of activated sludge in the competitive growth of filamentous and non filamentous bacteria. Water Sci Technol 23, 899-905.

Nakamura, K., Hiraishi, A., Yoshimi, Y., Kawaharasaki, M., Masuda, K. \& Kamagata, Y. (1995). Microlunatus phosphovorus gen. nov., sp. nov., a new gram-positive polyphosphate- accumulating bacterium isolated from activated sludge. Int $J$ Syst Bacteriol 45, 17-22.

Pitcher, D. G. \& Collins, M. D. (1991). Phylogenetic analysis of some LL-diaminopimelic acid-containing coryneform bacteria from human skin: description of Propionibacterium innocum $\mathrm{sp}$. nov. FEMS Microbiol Lett 84, 295-300.

Randall, A. A. (1994). The effect of substrate chemistry on enhanced biological phosphorus removal, intracellular phosphate form and location, and the resulting population structure of sequencing batch reactors receiving synthetic wastewater. $\mathrm{PhD}$ thesis, Auburn University.

Reasoner, D. J. \& Geldreich, E. E. (1985). A new medium for the enumeration and subculture of bacteria from potable water. Appl Environ Microbiol 49, 1-7.

Rees, G. N., Vasiliadis, G., May, J. W. \& Bayly, R. C. (1992). Differentiation of polyphosphate and poly- $\beta$-hydroxybutyrate granules in an Acinetobacter sp. isolated from activated sludge. FEMS Microbiol Lett 94, 171-174.

Schaal, K. P. (1986). Genus Arachnia. In Bergey's Manual of Systematic Bacteriology, vol. 2, pp. 1332-1342. Edited by P. H. A. Sneath, N. S. Mair, M. E. Sharpe \& J. G. Holt. Baltimore: Williams \& Wilkins.

Schleifer, K.-H. \& Seidl, P. H. (1985).Chemical composition and structure of murein. In Chemical Methods in Bacterial Systematics, pp. 201-219. Edited by M. Goodfellow \& D. E. Minnikin. London: Academic Press.

Schumann, P., Prauser, H., Rainey, F. A., Stackebrandt, E. \& Hirsch, P. (1997). Friedmanniella antarctica gen. nov., sp. nov., an LL-diaminopimelic acid containing actinomycete from Antarctic Sandstone. Int J Syst Bacteriol 47, 278-283.

Seviour, R. J., Pethica, L. M. \& McClure, S. (1984). A simple modified procedure for preparing microbial cells for scanning electron microscopy. Microbiol Methods 3, 1-5.

Skerman, V. B. D. (1968). A new type of micromanipulator and microforge. J Gen Microbiol 54, 287-297.

Smibert, R. M. \& Krieg, N. L. (1994). Phenotypic characterization. In Methods for General and Molecular Bacteriology, pp. 607-654. Edited by P. Gerhardt, R. G. E. Murray, W. A. Wood \& N. R. Krieg. Washington, DC: American Society for Microbiology.

Sneath, P. H. A. (1978). Classification of microorganisms. In Essays in Microbiology, pp. 9/2-9/31. Edited by J. R. Norris \& M. H. Richmond. Chichester: Wiley.

Sneath, P. H. A. \& Sokal, R. R. (1973). Numerical Taxonomy. The Principles and Practices of Numerical Classification. San Francisco: W. H. Freeman.

Stackebrandt, E. \& Goebel, B. M. (1994). Taxonomic note: a place for DNA-DNA reassociation and 16S rRNA sequence analysis in the present species definition in bacteriology. Int $J$ Syst Bacteriol 44, 846-849.

Stackebrandt, E., Rainey, F. A. \& Ward-Rainey, N. L. (1997). Proposal for a new hierarchic classification system, Actinobacteria classis nov. Int J Syst Bacteriol 47, 479-491.

Tamura, T., Takeuchi, M. \& Yokota, A. (1994). Luteococcus japonicus gen. nov., sp. nov., a new gram-positive coccus with LL-diaminopimelic acid in the cell wall. Int J Syst Bacteriol 44, 348-356.

Ubukata, Y. (1994). Some physiological characteristics of a phosphate removing bacterium isolated from anaerobic/ aerobic activated sludge. Water Sci Tech 30, 229-235.

Wagner, M., Erhart, R., Manz, W., Amann, R., Lemmer, H., Wedi, 
D. \& Schleifer, K.-H. (1994). Development of rRNA-targeted oligonucleotide probe specific for the genus Acinetobacter and its application for in situ monitoring in activated sludge. Appl Environ Microbiol 60, 792-800.

Wayne, L. G., Brenner, D. J., Colwell, R. R. \& 9 other authors (1987). International Committee on Systematic Bacteriology. Report of the ad hoc committee on reconciliation of approaches to bacterial systematics. Int $J$ Syst Bacteriol 37, 463-464.

Winker, S. \& Woese, C. R. (1991). A definition of the domain Archaea, Bacteria and Eukarya in terms of small ribosomal RNA characteristics. Syst Appl Microbiol 14, 305-310.
Yamada, K. \& Komagata, K. (1972). Taxonomic studies on coryneform bacteria. IV. Morphological, cultural, biochemical, and physiological characteristics. J Gen Microbiol 18, 399-416. Yokota, A., Tamura, T., Takeuchi, M., Weiss, N. \& Stackebrandt, E. (1994). Transfer of Propionibacterium innocuum Pitcher \& Collins 1991 to Propioniferax gen. nov. as Propioniferax innocua comb. nov. Int J Syst Bacteriol 44, 579-582.

Yoshimi, Y., Hiraishi, A. \& Nakamura, K. (1996). Isolation and characterization of Microsphaera multipartita gen. nov., sp. nov., a polysaccharide accumulating Gram-positive bacterium from activated sludge. Int $J$ Syst Bacteriol 46, 519-525. 